\title{
A New Generation of Taiwanese at the Ballot Box
}

Young voters and the presidential election of January 2012

\section{Tanguy LePesant}

Traducteur : Michael Black

\section{OpenEdition}

\section{Journals}

Édition électronique

URL : http://journals.openedition.org/chinaperspectives/5883

DOI : 10.4000/chinaperspectives.5883

ISSN : 1996-4617

\section{Éditeur}

Centre d'étude français sur la Chine contemporaine

\section{Édition imprimée}

Date de publication : 4 juin 2012

Pagination : 71-79

ISSN : 2070-3449

\section{Référence électronique}

Tanguy LePesant, «A New Generation of Taiwanese at the Ballot Box », China Perspectives [En ligne] 2012/2 | 2012, mis en ligne le 30 juin 2015, consulté le 14 novembre 2019. URL : http:// journals.openedition.org/chinaperspectives/5883 


\title{
A New Generation of Taiwanese
}

\section{at the Ballot Box}

\author{
Young voters and the presidential election of January 2012
}

\author{
TANGUY LE PESANT
}

\begin{abstract}
The re-election of Ma Ying-jeou on 14 January 2012 was not as close as had been anticipated. This was in particular because he managed to win the support of some young voters, who at the beginning of the campaign were massively in favour of Tsai Ing-wen. In order to highlight the reasons why Taiwanese in the 20-to-29 age bracket changed their minds, this article analyses their perception of the two candidates, their main preoccupations, and their position in relation to the main themes of the campaign: the economic and social situation, identification with Taiwan, the island's international status, and relations with China.
\end{abstract}

KEYWORDS: Taiwan, elections, youth, generation, Tsai Ing-wen, Ma Ying-jeou, China.

W hether in verbal or visual form, the discourse produced by the Kuomintang (KMT) and the Democratic Progressive Party (DPP) during the campaign for the presidential and legislative elections, which were held jointly on 14 January 2012, show clearly the determination of both parties to win over voters in the centre. In this sense, these elections are a continuation of those in 2008. In parallel with a defence of its record and of the advantages of the rapprochement with the People's Republic of China (PRC), the Kuomintang once again put forward its identification with Taiwan and its commitment to the protection of the interests of the population. (1) Pride in being Taiwanese, the love of the island as "home," and the valuing of "unity in diversity" - all favourite DPP themes - were at the heart of the symbolic staging of campaign rallies and TV spots during the whole campaign.

But the convergence of themes was not only the result of tactical choices by the KMT. Under the leadership of Tsai Ing-wen, the DPP also opted for an approach aimed at winning over undecided voters and those disenchanted by Ma Ying-jeou's presidency. Aware of the impossibility of calling into question the liberalisation of trade with China, which is now considered by the majority of the population as essential to the maintenance of prosperity, (2) the DPP centred its campaign on increasing social inequality and on how to resolve the economic problems of ordinary Taiwanese, rather than anti-Chinese and openly pro-independence rhetoric. Moreover, apart from the intense debates that followed Ma Ying-jeou's proposal to sign a peace agreement with China in the decade following his re-election, the theme of the Chinese military threat was significantly absent from the campaign.

All in all, both the KMT and the DPP pushed their long-term objectives into the background - unification for the former, and for the latter international recognition of an undisputable reality, the independence of Taiwan. Putting aside their pan-Chinese and Taiwanese nationalist rhetorics, both parties built their campaigns on modulated versions of the same themes: identification with Taiwan, the over-riding importance of protecting the economic interests and dignity of the Taiwanese population, ways of assuring the continuing prosperity of the island, and the definition of a modus vivendi with the PRC. However one must go beyond this convergence in order to identify the factors that led, on the one hand, to the re-election of MaYingjeou, but with a much smaller lead (51.6 percent of the vote as opposed to 58.45 percent in 2008), and on the other to the relatively weak showing of Tsai Ing-wen, who received only 45.63 percent of the vote, when many observers were predicting a narrow victory by one or the other of the candidates. (3)

With a view to contributing to the analysis of the results of these elections, this article focuses particularly on the segment of the electorate aged between 20 and 29 at the time of the vote. They made up almost a fifth (19 percent) of the 18 million voters, and around 1.2 million of them had the opportunity to vote for the first time. ${ }^{(4)}$ Perceived as one of the keys to victory by most observers because of their low party identification and their indecision, these young voters, and more especially the "first-time voters" (shoutouzu 首投族), were the main target of the campaigns on both sides. This article will seek to explain why, having pinned their hopes on the candidacy of Tsai Ing-wen right up to the last weeks, the majority of the 20-29 age group finally decided to vote for Ma Ying-jeou. It will therefore analyse the perception young voters had of the two parties and of their candidates, as well as their attitude to the themes of the campaign.

1. The KMT thus continued with two themes that had been put forward in the preceding campaign, but which had then been abandoned in favour of a cultural and educational policy that sought to "re-sinicise" Taiwan

2. The "Ten Year Political Platform" (shinian zhenggang 十年政綱) drawn up by the DPP for the elections reflects this position, while stating that China is just one part of the world. For the section on "trade between the two shores" (liang an jingmao 兩岸經貿 ), see: http://10.iing.tw/ 2011/08/blog-post_21.html (in Mandarin; consulted on 7 May 2012).

3. The third candidate in the presidential election, Soong Chu-yu, received only 2.77 percent of the vote, and his party, the Qinmindang (親民黨), three of the 113 seats in the Legislative Yuan. The Kuomintang got 64 seats and the "green" side 43, of which 40 went to the DPP and three to the Alliance for the Union of Taiwan. Given the weakness of these results and the fact that the legislative elections were largely overshadowed by the presidential contest, this article will deal essentially with the campaigns of Ma Ying-jeou and Tsai Ing-wen.

4. In Taiwan the legal voting age is 20 


\section{Research methods: Structuring tendencies and the following of the campaign}

The analysis in this article is the result of a comparison of surveys carried out to identify the structural lines of the vote among voters who were aged between 20 and 29 at the time of the poll, and to follow opinion among this section of the electorate during the whole campaign. Following Karl Mannheim's work, it has been shown elsewhere that young people born in the 1980s (or more precisely between 1982 and 1991) make up a separate generation in that they were socialised in an environment radically different from that of their elders: a state - the "Republic of China on Taiwan" - whose identity, while hybrid, was symbolically recentred on the territory of the island alone; and a prosperous society undergoing democratic consolidation, increasingly open to trade with China and to the influence of the rest of the world on its values and its modes of consumption. ${ }^{(5)}$ This socialisation framework makes it possible to envisage highlighting certain characteristics specific to this post-reform generation and likely to influence the political and identity position of its members, and therefore their vote. However, it is also essential to take into account the cyclical factors linked to the campaign itself: the issues raised, the symbolic forms of discourse, and the events that marked it.

Two surveys provide data showing the general position of the young voters. The first is an opinion poll conducted by the author in spring 2012 using a paper questionnaire made up of 82 questions (of which 23 were openended) distributed in 15 institutions of higher education spread over the whole of the territory of Taiwan. ${ }^{(6)}$ The sample was built up on the basis of statistics provided by the Ministry of Education for the university year 20092010. The departments in each institution were chosen as part of a nonprobabilistic method of sampling, i.e., not by carrying out a blind draw of the individuals chosen, but by establishing quotas that reflected the composition of the student body according to three criteria: gender, field of study, and geographical distribution. These criteria were retained when it came to the issues raised in the questionnaire (ethnicity, national identity, party identification, perception of China, defensive spirit, values) and to the influence they might have on the answers provided. The division between public and private institutions was also taken into account, but with less precision; students enrolled in public institutions were over-represented, amounting to half (50.8 percent) of those questioned whereas they amounted to only a third (32.2 percent) of those enrolled in the university year 2009-2010. Ethnicity, however, was not used as a factor in the construction of quotas, as one of the main objectives of the questionnaire was to avoid the injunctive effect of the categorisation that is usually used in opinion polls in Taiwan. This was in order to find out to what extent these identity categories remain relevant to this generation. A total of 575 answers were analysed. In order to ensure as high a return as possible, as well the maintenance of the quotas, a teacher was contacted in each of the institutions selected, and the teacher agreed to pass on the questionnaires to the students, who were free, if they so wished, to return their answers in an envelope in order to guarantee confidentiality. In terms of analysing the behaviour of voters between 20 and 29 years old, it must be emphasised that the data provided presents a bias towards those young people who benefit from higher education. According to the Ministry of Education, in 20092010, slightly less than two-thirds (64.5 percent) of the age bracket concerned were in higher education.

A second, much smaller survey, carried out during the spring and summer of 2011 , completed the results of this questionnaire by focusing on eco- nomic questions. It was made up of the information provided by 27 young people aged 24 to 30 who had already been in the job market for at least a year. The people interviewed were selected through the intermediary of five assistants, who were each asked to recruit five or six people according to limited criteria: gender, age, and field of work. These were asked to provide written answers to ten open questions dealing with both the state of the Taiwanese economy (job market, working conditions, wages, purchasing power, income inequality, etc.) and the evolution in economic relations with China.

These data, which made it possible to highlight the structural tendencies of the choices made by this segment of the electorate, were complemented by a more dynamic approach to the campaign. This consisted firstly of analysis of the discourse produced by each side during the election debates and through the dozens of campaign clips broadcast on TV and on the Web. A total of 77 videos were watched, of which 49 were produced by the KMT ${ }^{(7)}$ and 28 by the DPP. ${ }^{(8)}$ The special attention given to these films is justified by the fact that they form rhetorical and symbolic concentrates of the discourse of each side and that they were often aimed at the young.

The dynamic monitoring of the position of young voters towards this discourse, as well as their expectations and opinions of the parties, candidates, and programmes, was carried out in two ways: through interviews conducted during the campaign, in particular during rallies; and in focus groups organised with students in November and December 2011, as well as in March 2012. Each of them included four to six people who were already of voting age in 2008. One of the objectives was to collect their opinions and place them in a comparative perspective with 2008.

\section{The image of the candidates and their parties at the beginning of the campaign}

Tsai Ing-wen, from the time of her victory at the DPP primary at the end of April 2011 and her entry into the presidential race, seemed to be in a position to defeat Ma Ying-jeou. Several opinion polls showed that she had high popularity ratings and voter support. Three polls carried out on 27 April for media close to the KMT, United Daily News (Lianhebao), The China Times (Zhongguoshibao), and the cable TV station TVBS, showed that the gap between the two candidates (Soong Chu-yu had not yet declared his candidacy) was paper thin, with Tsai leading by 1 and 0.4 points in the first two polls, and Ma 1 point ahead in the third.(9) The campaign looked difficult for the incumbent president. The work of reorganisation carried out by Tsai Ing-wen since her accession to the presidency of the DPP three years earlier had borne fruit, making it possible to turn the page on Chen Shui-bian and to win back part of the electorate that had been lost in 2008. ${ }^{(10)}$ At least

5. Tanguy Le Pesant, "Generational Change and Ethnicity among 1980s-born Taiwanese," Journal of Current Chinese Affairs, vol. 40, no. 1, 2011, pp. 137-139

6. For a more detailed description of the sampling method, see: ibid., pp. 141-143.

7. Forty-six of them were online, on the YouTube link of the KMT campaign site, "Taiwanbravo": www.youtube.com/user/taiwanbravotw (consulted on 7 May 2012).

8. While they are no longer online on Tsai Ing-wen's campaign site, they can be found on YouTube or from the blog Letters from Taiwan: http://lettersfromtaiwan.tumblr.com/post/13637731738/ taiwan-election-campaign-videos (consulted on 7 May 2012).

9. Taipei Times, 29 April 2011, p. 1.

10. The DPP's image was badly damaged by accusations of fraud made against Chen Shui-bian and his entourage. After a trial that raised a number of questions about the independence of the judicial system, Chen was sentenced, in November 2010, to 17 years and 6 months in prison. J. Bruce Jacobs, Democratizing Taiwan, Brill, Leiden, Boston, 2012, pp. 261-266. 
this was the impression given by the success of the DPP in the partial legislative elections, and the good results obtained in the local elections of December 2010. Conversely Ma's popularity had been very low since the summer of 2009. ${ }^{(11)}$

Most of the polls carried out in the months following the selection of the two candidates showed that the crisis facing Ma was particularly serious among the young voters who had largely contributed to his victory in 2008. According to the TVBS poll referred to above, at the end of April 2011, Tsai Ing-wen had 51 percent of voting intentions among 20-to-29-year-olds, as against 42 percent for Ma Ying-jeou. In mid-September, the gap was just as wide, with Tsai ahead of Ma by 12 points (50 to 38 percent). (12) The Blues became quickly aware of the crisis, which was called "extreme" by one of its MPs, Wu Yu-sheng (吳育昇). ${ }^{(13)}$ On the occasion of the third anniversary of Ma's nomination, on 20 May 2011, the pro-government newspapers did not conceal their anxiety about the president's chances of re-election. ${ }^{(14)}$ Among the reasons given by Lianhebao were the loss of credibility of a president who now lacked charisma and who seemed tired in the face of the freshness and dynamism of the DPP candidate.

The interviews carried out in the spring and autumn of 2011 and the discussions held in the framework of the focus groups confirmed this impression and highlighted two trends. On the one hand was the re-mobilisation of young Green voters who had abstained in 2008, disillusioned by corruption scandals involving Chen Shui-bian and his entourage, and by a nationalism that was seen as too radical because it excluded any possibility of dialogue with China and disowned the Chinese dimension of Taiwanese identity. On the other hand were the serious doubts felt by the portion of the young electorate who had supported $\mathrm{Ma}$ in 2008 , and who had often pinned hopes on the candidacy of a politician to whom they attributed numerous qualities. They saw in him an upright, dynamic, and charismatic man whose example raised the aspirations of the Kuomintang; a moderate who would be able to find a modus vivendi with China while enjoying favourable relations with the United States; endowed with an international education and profile (Harvard Law PhD, excellent English) that would certainly allow him to fly the colours of Taiwan prominently; dynamic and with experience at all the administrative levels (secretary to Chiang Ching-kuo, Minister, Mayor of Taipei from 1998 to 2006).

But these interviews and the survey carried out in 2010 also highlighted the low level of party identification among the young born in the 1980s. Only 38.6 percent of the students who answered the questionnaires supported a party: 19.5 percent favoured the KMT, 17.9 percent the DPP and 1.2 percent a different party. This has two consequences: a very high level of abstention, especially among first-time voters, ${ }^{(15)}$ and a shift in voting that can be massive between elections, but also throughout a campaign. The high volatility of this age group's vote is firstly explained by their attitude to politics. However, its characteristics need to be spelt out and a distinction needs to be made between behaviour stemming from generational factors and those that should be attributed to an "age-group effect."

It is often said that Taiwanese born after the beginning of the 1980s show no interest in politics. Some observers even see this as the principal characteristic of a generation born into smaller and relatively prosperous families, who grew up in a democratic and much more permissive consumer society. ${ }^{(16)}$ In other words, to its detractors, Taiwanese youth has been taken over by the "dark side of individualism," as described by Charles Taylor in the case of the West. ${ }^{(17)}$ Trapped in destructive relativism, excessive selfpreoccupation, and narcissistic introversion, they are deemed to replace po- litical, social, and to a lesser extent spiritual concerns that transcend the Self with an ideology of self-realisation reduced to bland consumer pleasures.

While these criticisms do indeed apply to a portion of Taiwanese youth, it would be excessive to extend them to the whole post-reform generation. The answers to the 2010 questionnaire show a much more finely-shaded reality. Only a third (34.6 percent) of the students questioned say they have either "absolutely no interest" (15.8 percent) or "very little interest" (18.8 percent) in political matters, while another third (37.7 percent) are "moderately" interested and 2.4 percent have "no opinion" on the subject. In contrast, a quarter of them (25.4 percent) show either "some interest" (21.9 percent) or "a lot of interest" (3.5 percent) in politics. As I have shown elsewhere, the lack of interest in politics must also be attributed to the "agegroup effect." (18) Parental pressure, the imperative of success, an overloaded schedule, the daily hours of cramming, and the frantic rhythm to which most schoolchildren and high school students are subjected enclose them in a "school bubble" from which they emerge only after the university entrance examinations. This bubble keeps them outside the concerns of the "real world," and then the existential shock produced by its bursting generates a delayed political socialisation and certainly contributes to intensifying the impression of narcissistic introversion. However, following up on a number of young people during their university programme and after their entry into the job market shows that this generation is far from being entirely numbed by the opium of consumerism. Among the students whose progress I have been able to follow, more than a few have developed awareness of citizenship over the years. But their growing interest in public affairs is often expressed in a disembodied form, through the computer, and/or in a very localised manner. This is why it may be overlooked by an observer whose "sociological radar" would seek out institutionalised movements, affiliated to a political side or party, over the long-term, and physically present in the streets and public spaces.

The refusal to commit to a political side is also due to the deep disgust that young Taiwanese citizens show for the political scene as they perceive it, which is to say one made up of sterile disagreements, of dirty tricks and baseless mutual accusations, of manipulations of all sorts, of abuses of power, and of corruption. Three-quarters (74.4 percent) of the students questioned in 2010 about the quality of the Taiwanese political environment and debates considered that they are "bad" (46.2 percent) or "extremely bad" (28.2 percent). Only 15 (2.6 percent) thought the contrary.

11. Frank Muyard, "Analyse de la présidence de Ma Ying-jeou à mi-mandat" (A mid-term analysis of Ma Ying-jeou's presidency), Perspectives chinoises, 2010/3, pp. 14 and 19-20.

12. Poll taken by the TVBS Poll Centre between 20 and 22 September 2011. The sample was made up exclusively of people over 20 who stated their intention to vote on election day. The remaining 12 percent intended to vote but did not yet know for whom.

13. Taipei Times, 29 April 2011, p. 1

14. Lianhebao, 20 May 2011, p. A2 ; Wangbao, 20 May 2011, p. A2.

15. According to a survey of first-time voters carried out by the Observation Group on National Politics (shoutouzu guozheng guanchatuan 首投族國政觀察團) published at the end of December 2011 , half of the voters who had the opportunity to vote for the first time in a presidential election had abstained in 2008 .

16. Yvonne Chang and Joanne Chen, "Strawberries the Frame," Taiwan Review, vol. 57, no. 10, October 2007, http://taiwanreview.nat.gov.tw/ct.asp?xltem $=24696 \& C+$ Node $=128$ (consulted on 30 March 2011).

17. Charles Taylor, The Malaise of Modernity, Concord (ON), Anansi, 1991, p. 4.

18. On this subject, see: Jean-Pierre Cabestan and Tanguy Le Pesant, L'esprit de défense de Taiwan face à la Chine. La jeunesse taiwanaise face à la tentation de la Chine (Taiwan's spirit of defence against China: Young Taiwanese and the temptation of China), L'Harmattan, 2009, pp. 76-86. 
All in all, given the low level of politicisation of this fringe of the electorate, the frequent difficulty in making a clear distinction between the two sides, and a widespread distrust of the parties, the decision as to whether or not to vote and the choice of candidate do not depend so much on an individual's adherence to the values and objectives of a political organisation as on the image projected by a candidate, and on his or her ability to convince them that he or she is different - and will be able not only to lead his or her party in a new direction, but also to give a new impetus to Taiwan in economic matters and on the international scene.

In 2008, Ma Ying-jeou's campaign team was able to take advantage of his "star status" and of the goodwill he had accumulated during his two terms as Mayor of Taipei. Led by King Pu-tsung (金溥聰), it sought to break away from the two previous campaigns, during which Lien Chan and the Kuomintang had never managed to shake off the image of "an oldster's party" on the defensive. In 2008, the KMT did not just settle for campaigning on the same issues as the DPP. It also copied its visual and acoustic aesthetic codes (the emphasis on the diversity of the landscapes and cultures of Taiwan, the recurrent use of the island's shape to symbolise the Taiwanese political community, the cover versions of songs previously used by the DPP) to such an extent that it was sometimes difficult to know which of the two parties had produced certain advertisements before the last few frames. ${ }^{(19)}$ In parallel, the rejuvenation of the Kuomintang's image was effected by highlighting the dynamism of Ma Ying-jeou. Photogenic and a sportsman of irreproachable integrity, he embodied the new KMT and the possibility, or at least the hope, of a new inspiration for Taiwan, while the DPP had been increasingly embroiled in corruption scandals for several years.

But after four years as head of state, Ma Ying-jeou could no longer count on the novelty of his candidacy to persuade young voters. Physically worn out, frequently criticised for his incompetence, his U-turns and his hypocrisy, he also had to defend a highly controversial economic record very far from the slogan "6-3-3" that summarised the promise made in 2008 of 6 percent annual growth, GDP of US\$30,000 per capita, and a reduction in unemployment to below 3 percent. The Kuomintang could be said to be back to square one. Its efforts to win back young voters were very much in evidence throughout the campaign. They are mirrored in the very choice of logo and of the slogan in "Taiwanese Mandarin" (Taiwan guoyu 台灣國語). Both borrow from the "youth culture": a thumb in the form of Taiwan pointing upward that recalls the one used on Facebook, accompanied by "Go Taiwan" (台灣加油) or "Co Super Taiwan" (Taiwan jiayouzan 台灣加油讚), the latter being also used on Facebook to show that someone appreciates a post. Ma Ying-jeou's team, led once again by King Pu-tsung, also appointed two spokespeople under 30:Yin Wei (殷瑋) and Ma Wei-kuo (馬瑋國). The choice of the former was judicious: before joining the KMT, he had attracted notice in 2010 for his opposition to the signing of the Economic Cooperation Framework Agreement (ECFA) with China. The support of both spokespeople for Ma was highlighted in several video sequences that were part of a range of campaign clips clearly aimed at reaching young voters, for example the rock clip with the English title "We Are One," the short film in two tenminute parts called "The Girl with the Flag" (guoqi nühai 國旗女孩), which we will return to later, and an edited version of Ma Ying-jeou's meetings and discussions with students in several universities. The Kuomintang also fielded ten candidates aged under 40 in the legislative elections.

Ma's opponent, Tsai Ing-wen, had several assets with which to embody a new fervour. Aged 55, she had the profile of an academic trained abroad, which was relatively similar to that of her rival, but with more freshness.

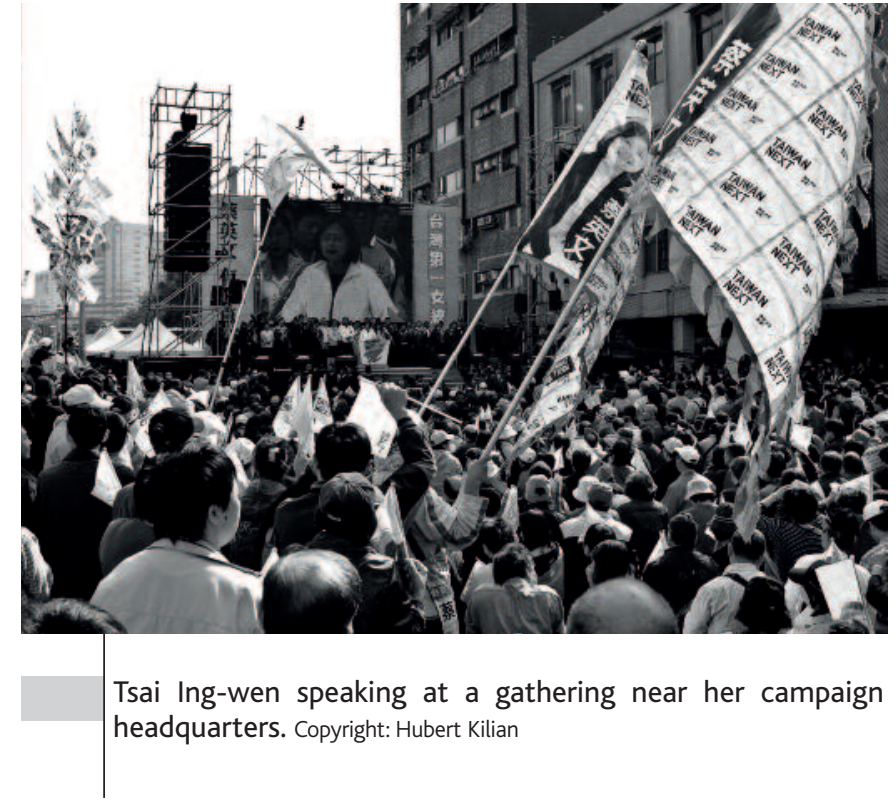

After studying Law at Cornell and the London School of Economics, she had taught for several years. During Chen Shui-bian's terms she had been Minister for Mainland Affairs from 2000 to 2004, and Deputy Prime Minister in 2006-2007. After the failure of the DPP ticket of Hsieh Chang-ting and Su Tseng-chang, which had received only 41.55 percent of the vote, she had taken over the leadership of a deeply troubled DPP in May 2008.

Her association with the Chen government could have damaged her chances with the centrist electorate. Indeed, the KMT sought several times to present her as close to the former president, and therefore as an extremist separatist. Wrong-footing these accusations by presenting her candidacy as the result of four years of reorganisation and of repositioning in the centre of the political field after the stinging defeats suffered by the DPP between 2005 and 2008, Tsai clearly sought to make people forget the DPP's dark years by embodying its new face, moderate and modern, and its ability to govern the country once again. Tsai's campaign team opted for a complete break from the visual codes, themes, and tone that had been used up to then. In visual terms, the colour green normally used by the DPP in reference to the party's flag was replaced by yellow, dark pink, and orange. The slogan in English "Taiwan Next" on a yellow arrow tilted upwards and associated with the phrase "Let's Decide Our Future Now" (xianzai jueding weilai 現在 決定未來) summarised in itself the general positioning of the campaign decided by Tsai: focused on the island's future rather than based on the legitimacy the DPP could draw from its past struggles for democracy; and centred on Taiwan and the real day-to-day problems experienced by the population rather than on separatist rhetoric, on an impossible accession to the UN, or on denunciation of the Chinese threat. The tone was controlled, with Tsai Ing-wen making use of her academic status to try to appear close to the people without being populist.

The style adopted by Tsai Ing-wen no doubt cost her votes among the older voters of the south of Taiwan, who could not identify with a campaign so different from those of her predecessors. The interviews carried out indicate that, on the other hand, it certainly contributed to reassuring and arousing the interest of young voters.

19. Tanguy Le Pesant, "Chine-Taiwan: le retour du Kuomintang" (China and Taiwan: The return of the Kuomintang), Politique étrangère, 2008, no. 2, pp. 295-306. 


\section{The concerns of young voters about the future}

The support Tsai enjoyed from at the beginning of the campaign among 20-to-29-year-olds can also be explained by the fact that the criticisms aimed at Ma's government were similar to the anxieties of that fringe of the electorate about its future. The DPP spotlighted the internal problems of Taiwan and the necessity of solving them by putting in place a policy of sustainable development in the wider sense, which is to say economic growth that is not produced to the detriment of an already seriously damaged natural environment, but which would also be used to improve social and generational justice.

Tsai Ing-wen and her team tried to show that the Ma government's economic development decisions entailed the sacrifice of the present and future living conditions of a large part of the Taiwanese population. In environmental matters, their attacks were concentrated on nuclear power and Ma Ying-jeou's determination to carry on with the construction of a fourth power plant despite the lessons of the Fukushima disaster. But it was especially the economic criticisms that made it possible for Tsai to score points with young voters. At the core of these criticisms was the deterioration of their living and working conditions. A series of five very short films on the theme "President Ma, you have broken a record" (Ma zongtong nin po jilu le 馬總統您破記錄了) referred, for example, to the difficulties facing those who are entering the job market or want to have a family: the high rate of unemployment among young graduates (12.97 percent of 20-to24-year-olds in 2011); the impossibility of becoming a property owner in Taipei; the fact that, in contrast with the cost of living, salaries were not rising and that in 2010, 3.6 million employees earned less than 30,000 Taiwanese dollars (NT\$) per month (about 750 euros); the increasing inequalities of income; and Taiwan's rapidly increasing debt, which will weigh on future generations.

While the figures put forward by the DPP were sometimes called into question, an overwhelming majority of those interviewed in the course of 2011 agreed with these criticisms. It must be said that the growth in GDP (10 percent in 2010 and around 4 percent in 2011) and "competitivity gains" on which the government put much emphasis conceal the deterioration in the real working conditions of the majority of Taiwanese, and the young in particular, whose salaries continue to shrink while their working days grow longer. According to a survey carried out by the employment agency 104 Job Bank in the spring of 2011, the 639 companies surveyed were prepared to pay an average monthly salary of 26,432 NT\$ to an employee who had just obtained a degree. (20) Five years earlier, according to government figures, the average salary offered for a first job was 26,700 NT\$, which already amounted to a drop of 762 NT\$ in comparison with 1998. (21)

Over three-quarters (77 percent) of students who responded to a survey of first-time voters carried out in 20 universities at the end of 2011 by Observation Group on National Politics were disappointed by the government's lack of effort to resolve the problem of unemployment and of the low salaries paid to the young. (22) Most of the students I interviewed in the course of 2011, including a large part of the 27 who had already entered the job market, believed that Ma Ying-jeou had not managed to improve their situation. On the contrary, as they saw it, several of his initiatives had had a pernicious effect, for example the policy of subsidies offered by the government, beginning in 2009 , to companies that recruited a young grad- uate for a salary set at 22,000 NT\$ on a one-year contract. This policy was originally intended to reduce unemployment at a time when the recession was hitting the Taiwanese economy hard. In many cases it backfired, however, since it provided employers with an excuse to reduce salaries to the level of what they presented as being the standard set by the government. Low salaries are combined with ever longer working days. ${ }^{(23)}$ In 2012 the Taiwanese worked an average of 181.2 hours per month, or 2,174 hours per year. ${ }^{(24)}$ If Taiwan were a member of the OECD, the island would be the second country where people spent the highest number of hours at work, just behind South Korea (2,193 hours per person in 2010). (25) But these are only the hours declared by employers. A survey carried out in the spring of 2011 shows that four-fifths of Taiwanese office workers worked between 10 and

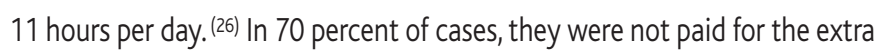
hours worked.

Far from the campaign promises made in 2008 , the continuing deterioration of working conditions under Ma Ying-jeou's presidency shows the limitations of the unprecedented acceleration of the liberalisation of trade with China, despite its having been presented by the KMT government as the solutions to all Taiwan's ills. At the time of the signing of the Economic Cooperation Framework Agreement (ECFA) at the end of June 2010, the Ma administration was accordingly insisting that it would protect Taiwan from economic marginalisation when the PRC was pushing for the establishment of vast free trade areas in the region. However, as has been pointed out by Philippe Chevalérias, while Taiwan is not in reality as economically isolated as the Ma government would have people believe, its economy faces structural problems that the ECFA and the liberalisation of trade with China cannot resolve. ${ }^{(27)}$

The abolition of most of the restrictions on investment and technology transfer to China do indeed encourage Taiwanese companies not to revise a growth model dating back to the early 1990s and based on a headlong rush to exploit low labour costs in China. (28) The logic of short-term profitability drains away a major part of investment and brainpower towards the quest for economies of scale by the transfer of production to China, to the detriment of strategies of increasing margin by the creation of innovative or high-end products and the development of internationally-recognised brands. Thus, with a few exceptions (HTC, Acer, Asus), Taiwanese companies remain trapped in a globalised chain of command in which they occupy the highly uncomfortable position of subcontractor. In order to remain competitive, they seek to keep labour costs as low as possible by reducing wages and resorting to unpaid overtime work. The first to suffer from

20. Taipei Times, 26 May 2011.

21. Yvonne Chang and Joanne Chen, op. cit.

22. Taipei Times, 29 December 2011, p. 3.

23. For some specific examples see "The young poor: 29,000 NT\$ per month after having studied in Europe" (青貧一族/留歐月薪兩萬九), Lianhebao, online edition, 28 August 2011.

24. Average working time in the industrial and services sector. Department of the Budget, of Accounts and of Statistics (DGBAS) of the Executive Yuan of the Republic of China (Taiwan), http://eng.dgbas.gov.tw/mp.asp? $\mathrm{mp}=2$ (consulted on 22 May 2012).

25. OECD, "Average annual hours actually worked per worker 2000-2010," http://stats.oecd.org/ Index.aspx? DataSetCode=ANHRS (consulted on 22 May 2012).

26. Survey carried out by the employment agency Yes 123 on a sample of 2,140 people. Taipei Times, 2 May 2011.

27. Philippe Chevaliéras, "The Taiwanese economy after the miracle," China Perspectives, 2010/3, pp. 35 and 41-42.

28. On this subject see the feature "Hopes and difficulties of the push to the West" (Da xi jin de xiwang yu aichou 大西進的希望與哀愁), CommonWealth (Tianxia) no. 481, 21 September- 4 October 2011. 
this development "model" are the least qualified employees and thus often the youngest.

However, the interviews show a more finely-shaded vision of economic integration between the two sides of the Taiwan strait. The people interviewed often recognise the negative impact of delocalisation on the wage levels in Taiwan because of the transfer of a major part of managerial jobs to the other side of the Strait and the heavy pressure from competition with the Chinese labour market. But they also believe that development of relations with China is vital for the Taiwanese economy. This is why the warming of relations between Taipei and Beijing and the signing of 15 technical agreements are generally well perceived. The majority of students are in favour of the establishment of direct air, sea, and postal connections as well as the opening to Chinese tourism. Where the ECFA is concerned, while they find it more difficult to come out clearly for or against, the agreement is only rarely rejected in its entirety and is more often perceived from the point of view put forward by the Kuomintang Government: it will endanger certain traditional sectors that are in any case bound to disappear in the short or medium term, but will ultimately make it possible to avoid marginalisation and make the economy more competitive.

During the survey I carried out in 2010, three-fifths (61.7 percent) of the students thought that, from a general point of view, China was a source of economic opportunity for Taiwan, while less than a quarter (23.8 percent) perceived a danger. This impression has become stronger since. The campaign conducted by the KMT and the media favourable to the government, based on Taiwan's good performance in the face of the world economic slowdown, has reinforced the idea that economic integration between the two shores is not without its negative aspects, but that the situation would be even worse if Taiwan could not hitch itself to China's growth. Faced with this situation, most of the young people interviewed adopt a fatalistic attitude, feeling that they can do nothing in the face of "market forces," or believing that it is down to individuals to equip themselves as well as possible in order to rise in the ranks and be able to get their head above water.

All in all, Tsai Ing-wen could emphasise the sufferings endured by the generation beginning adult life and entering the job market, and she could criticise the Ma government's inability to stop the deterioration of the job market and the impoverishment of the population, but it was difficult for her to attack the heart of the problem - the Taiwanese economy's excessive dependence on China - without putting her credibility at risk, so strong is the perception that the continued development of relations between the two shores is essential for Taiwan's economic survival. In the sphere of relations between Taiwan and China, Tsai Ing-wen could not therefore put forward a radically different project. She was forced to campaign on the KMT's preferred ground: the continuation of good relations with Beijing.

\section{Identification with Taiwan and the island's international status}

While left in the background, behind economic issues, identification with Taiwan and the island's status on the international scene were two other major themes. They are also two subjects that, despite misleading appearances, preoccupy young Taiwanese. However, as was the case in 2008, the DPP was not able to benefit from them, firstly because young voters are wary of the instrumentalisation of issues of identity, secondly because they do not draw a clear distinction between the values and objectives put forward by the DPP and the KMT, and finally because the KMT was careful to emphasise its local roots as well as the effective defence of Taiwan's international existence and the dignity of the Taiwanese through its policy of reconciliation with Beijing.

Young Taiwanese often say that they are tired of the constant emphasis on issues of identity. ${ }^{(29)}$ While they are reluctant to go into them, this is not because they do not consider them important, but because they feel that identification with Taiwan is a given, that it is shared by the overwhelming majority of the population and that they therefore refuse to join in with the game of manipulation and division of identity played by both sides. Thus almost two-thirds (63.7 percent) of those interviewed during the survey I carried out in the spring of 2010 either "strongly disapproved" (30.1 percent) or "disapproved" (33.6 percent) when asked if they "agreed with the idea put forward by some that 'loving Taiwan is supporting a native Taiwanese government'." They see accusations based on ethnicity as inappropriate. A person's place of birth or that of his/her ancestors should not presume loyalty to Taiwan. They consider ethnicity above all as a component in the construct of individual identity and do not perceive it according to a logic of opposition between a supposedly historically legitimate group of "Native Taiwanese" (benshengren 本省人) and a group of "Mainlanders" (waishengren 外省人), most of whom were born in Taiwan, but who are supposed to constantly seek redemption for the "original sin" of the circumstances of their parents' or grandparents' migration to the island. (30)

Likewise, students of the post-reform generation show a certain wariness towards the question of national identity, not because they don't care or because they reject the division of the world into nation states, but rather because they do not identify with the reductive formulation of the debate on the political scene and in the media sphere. To them, the binary and exclusive opposition between Taiwanese identity and Chinese identity does not make sense, because their identification with a Taiwanese nation-state is usually combined with the maintenance of Taiwan in the Chinese ethnocultural sphere. The data from the 2010 survey show that identification with Taiwan is very widely shared in this generation and that it does correspond to a national identity. ${ }^{(31)}$ Three quarters (74.8 percent) of the students who answered the questionnaire described themselves as either "Taiwanese" (40.9 percent) or both "Taiwanese and Chinese (Huaren)" (33.9 percent). Moreover, almost all of them ( 85.3 percent) declared themselves in favour of the independence of Taiwan if this could be achieved while maintaining good relations with the People's Republic. Only 4 percent were against, while 10.7 percent did not know. ${ }^{(32)}$ Other replies, for which space is not sufficient to go into detail here, reinforce the conclusion that most of the time, being "Taiwanese" to these young people does indeed mean having a feeling of

29. Shelley Rigger, "Taiwan's Rising Nationalism: Generation, Politics, and 'Taiwanese Nationalism'," Policy Studies, 26, East-West Center, Washington, 2006, p. 52

30. Tanguy Le Pesant, "Generational Change and Ethnicity among 1980s-born Taiwanese," art. cit.

31. In order to understand the real meaning of the identity categories "Taiwanese," "Chinese," and "Taiwanese and Chinese" to the people who respond to the surveys regularly conducted in Taiwan, the 2010 questionnaire widened the possibilities of reply in two ways. One was to distinguish between "Huaren" and "Zhongguoren" — where very often surveys carried out in Taiwan offer only "Zhongguoren" for the category which in English is translated by the single word "Chinese." This is notably the case in the surveys carried out every six months by the Chengchi University Election Study Centre that are often used by Western analysts. In the questionnaire I distributed, the range of choices was also widened by the possibility of placing one of the three terms (Taiwanese, Huaren, or Zhongguoren) before the other in the category of dual identity. In total, those questioned had ten answers available, of which one was open-ended, which made it possible for them to escape the rigidity of these categories by answering freely.

32. Almost exactly the same proportions reappear if the 195 people who defined themselves as both "Taiwanese and Huaren" are separated out: 84.6 percent supported independence if it could be achieved while maintaining good relations with China, 3.6 percent were opposed and 11.8 percent did not reply. 
belonging to a territorialised political community restricted to Taiwan, the Penghus, and a few dozen smaller islands: they expect the government to put the interests of Taiwan and of its population ahead of any other consideration; they claim the right to self-determination and believe that the improvement of Taiwan's international status must be among the government's priorities.

However, freed from the frictions of a nationalism that would have the sense of belonging to Taiwan exclude any form of identification with China, the national identity of this generation is characterised by a more positive attitude to the heterogeneity that constitutes the foundation of Taiwanese culture, and by a pride in being Taiwanese that does not mechanically imply rejection of the Chinese ethno-cultural basis of that identity. The questionnaire distributed in 2010 shows that only a fifth (20.5 percent) of the students opposed the idea put forward several times by Ma Ying-jeou that "the peoples on both sides of the strait are the descendants of the Emperors Yan and Huang," while over half (51.9 percent) said they either "agreed" or "agreed completely," and a quarter (26.4 percent) had no opinion on the question. ${ }^{(33)}$ But these blood ties and the recognition that Taiwan belongs to the Chinese cultural sphere do not translate into political terms. This is why most of the young who wish to combine a Chinese dimension with their Taiwanese national identity prefer to use the category "Huaren" 華人 (rather than "Zhongguoren" 中國人), the former having an ethno-cultural dimension while the latter has a more political meaning.

From this point of view, there is no contradiction between the affirmation of a Taiwanese national identity and the emphasis on a Chinese ethnicity. Nor is there any contradiction between the feeling of belonging to a Taiwanese political community that wishes to be independent and the desire to preserve the Chinese cultural heritage, and even the existence of the Republic of China on Taiwan as a melding together of two historical paths: that of a past specific to the island, and that of a state "born in China, but having grown and reached its democratic maturity in Taiwan." Thus in the eyes of the majority of the members of this generation, although Ma Yingjeou and many leading cadres are "Mainlanders" who stand up for the heritage of the Republic of China, their party is no less Taiwanese than the DPP. A tiny minority of the students questioned on this subject believed that the KMT was not a local party. ${ }^{(34)}$ The political dimension of the economic integration between the two shores does not seem so simple to them, and they do not see the KMT as a Chinese nationalist party seeking to "sell Taiwan" to China. On the contrary, many support it because they consider it the most likely to raise the status of Taiwan on the international scene. This was the first reason given by those students who stated their preference for the KMT in answer to the questionnaire distributed in 2010, ahead of "the promotion of economic development" and the opening of talks about peace.

MaYing-jeou and the Kuomintang made numerous efforts to confirm the impressions of young Taiwanese. They constantly underlined their identification with Taiwan, associated the defence of the Republic of China (ROC) with that of the interests and sovereignty of the island, and put forward what they considered to be the improvement of Taiwan's international situation thanks to the reopening of dialogue with Beijing. The KMT campaign team produced a number of films aimed at proving Ma's attachment to and identification with Taiwan, for example two interviews with his Hoklo and Hakka language teachers. All these films particularly emphasised the plurality of origins of the Taiwanese population and the cultural richness enjoyed by Taiwan because of this diversity. For example, this was the theme at the centre of the flagship song of the KMT campaign, the chorus of which, in Mandarin and English, was "Under the same sky, we are one" (同一片天 空, we are one). It opens with a poster for the film Seediq Bale and shows two young musicians setting off around Taiwan on a motorcycle to find the "different voices" of the island's inhabitants, who give them balloons of all colours, symbolising their ethnic and cultural diversity. In each place they stop, the clip names and emphasises the beauty of 20 regions, towns, and villages in Taiwan, emphasises its island character, works through certain aspects that are generally considered to be at the centre of "Taiwanese cultural identity" (baseball, a night market, a temple and religious practices), and emphasises the diversity in the origins of the Taiwanese population by presenting two extremes: a group of older women in Paiwan (排灣族) dress and a group of "new residents" (xinzhumin 新住民), an administrative category created to designate foreigners who are married to Taiwanese and have obtained naturalisation.

The importance given to foreigners who have come to settle in Taiwan, to their "love of the island," and their naturalisation seems to me particularly interesting because it reveals a new attempt to legitimise the place of Mainlanders within the Taiwanese population: in the end, they are only one among many waves of immigration to Taiwan, part of a chain that began long before their time and that is going to continue with the arrival of nonHan people and the consequent mixing of the population. In the clip "We are one," a row of "new residents" holds up balloons on which is written "We Love Taiwan" in Mandarin. Two of them then proudly display their Taiwanese identity cards. This sequence recalls two other KMT campaign clips. These are accounts in Mandarin given by foreigners who are naturalised Taiwanese. One is an American who has lived in Taiwan for 20 years, and did two years' military service there. The other is a woman of Franco-Dominican origin, married to a Hakka. Both praise Taiwan and make it clear that they do not wish to live anywhere else. The films end with the words "I am Taiwanese, I am a citizen of the Republic of China."

Here there appears a tactical move already used by the KMT in 2008, as well as every time it has been criticised for the nature of its links with the Chinese Communist Party and for its ultimate objective: concealing its return to a pan-Chinese nationalist ideology behind the promotion of a relationship of equivalency between the Republic of China and Taiwan. To do so, the KMT has played cleverly on the ambiguity of bringing together two symbolic markers: the flag of the ROC and the shape of the island of Taiwan. Ma Ying-jeou's whole campaign was in the colours of the flag, which was omnipresent in the electoral evenings, in the advertisements, and on all the ancillary merchandise. But while the overabundant use of the flag allowed the KMT to materialise the link between Taiwan and China through the history of the Republic and thus to mobilise the "Dark Blue" electorate, its very frequent association with the shape of the island was also supposed to recall its commitment to maintaining the sovereignty of Taiwan, the flag then being the symbol of the existence of Taiwan. The KMT campaign overflowed with different combinations of the flag with the shape of Taiwan. For example, when the two young musicians mentioned set off on their tour of

33. This formulation was notably present in Ma Ying-jeou's midterm speech, delivered on 20 May 2010.

34. The question asked was: "Some say that 'the Kuomintang is not a local party'. Do you agree with this point of view?" (有人說：「國民黨非本土政黨」，請問您同不同意這種說法?).Among the students who answered, 3.1 percent "agreed completely" and 10.4 percent "agreed," while 38.6 percent "disagreed" and 12.3 percent "disagreed absolutely." 13 percent felt that it "depended on the situation" and 21 percent had no opinion. 
Taiwan, a close-up shows the flag of the ROC cut into the shape of the island on the white background of their motorcycle helmets.

It must also be underlined that in the campaign films aimed at young voters, the state was very rarely called the "Republic of China" and much more often "Taiwan." In the short film "The Girl with the Flag" referred to above, the country at the centre of the story is Taiwan; the Republic of China is not mentioned once. And when, at the end of the film, the young heroine is at last able to say what is meant by the flag of the ROC that she has been given and with which she has travelled all over Taiwan, she refers only to the values of freedom, equality, and fraternity; not a word about its historical origins. Even though this vision is far from being its own, the KMT didn't get it wrong. This is how the young Taiwanese perceive and appropriate the flag: as the symbol of the existence of a Taiwanese state and the democratic values that it carries, but devoid of any reference to Greater China or to Chinese nationalism. The disappearance of the Republic of China behind Taiwan is also striking in the KMT slogan: "Go Taiwan."

Finally, in order to materialise the Ma administration's efforts in the defence of the sovereignty of Taiwan and of its existence on the international scene, its team based itself on what it presented as an unprecedented improvement in the status of Taiwan. In reality, the Kuomintang had only a very few victories to its credit. The "diplomatic truce" with China has allowed Taiwan to keep its 23 allies, but it has not led to a reduction in the pressure brought to bear by Beijing on the international community as a whole to eradicate the presence of the ROC. The KMT therefore seized on anything that might appear to be a success, such as the signing of agreements that allow Taiwanese nationals to travel without visas to 124 countries, in order to give substance to a vast communication campaign aimed at showing, on the one hand, that the international community approved the policy of détente in China-Taiwan relations, and on the other that the Taiwanese benefited from it directly. On this topic it is certain that the decision of the United States, announced on 22 December, to add Taiwan to the list of countries being considered for visa exemption for entry to American soil favoured the incumbent president. It materialised the Obama administration's support for Ma's re-election.

\section{The decisive influence of relations with China}

Apart from the few weeks of intense debate that followed Ma Ying-jeou's proposal to sign a peace agreement with China in the ten years that would follow his re-election, the question of Taiwan's political future, which is to say the choice between independence and reunification, remained in the background of the campaign. Both parties knew well that in order to win the elections they would have to set aside their long-term political objectives - the unification of Greater China for the KMT, and the formal recognition of the independence of Taiwan for the DPP. Ma Ying-jeou therefore restricted himself to the slogan of the "Three NOs" (no to unification, no to independence and no to the use of force), and Tsai Ing-wen stuck to the Resolution on the future of Taiwan passed by the DPP in 1999, which states that it is not necessary to declare independence, since the island is already a sovereign state constitutionally named the Republic of China.

However, Ma Ying-jeou's 17 October 2011 proposal to open peace talks with China forced the DPP to react and to concentrate its attacks on the potentially fatal dangers to the sovereignty of the state of Taiwan of such an initiative. (35) This lasted several weeks. Public reaction to this proposal was highly unfavourable, and it made Ma's popularity dip in the polls. But it also allowed the KMT to refocus the campaign on the importance of good relations with China and on the prerequisites for the continuation of dialogue with Beijing. In other words, this risky move resulted in a shift in the centre of gravity of the campaign. From a critique of Ma Ying-jeou's track record, it moved towards the absolute necessity of pursuing the institutionalisation of relations with China in order to avoid any risk of uncontrolled escalation. This shift was of course highly advantageous to Ma.The DPP initially scored some successes by underlining the fact that the Chinese negotiators would certainly demand that the unification of the two sides of the strait be written into the text of the agreement, which would eliminate any margin for manoeuvre in the definition of the political future of Taiwan. But the KMT then quickly succeeded in burying the controversial project by repeating that until favourable conditions emerged for the resolving the differences between the two shores, it was essential to maintain a framework within which discussions could continue while preserving the peace and the "status quo." This was the framework that the Ma administration had managed to establish on the basis of the "1992 Consensus" (jiuer gongshi 九二 共識), according to which Taipei and Beijing are alleged to have arrived at an oral agreement recognising the existence of a single China, with each side having its own interpretation of the meaning of this "One China."

During the last few weeks of campaigning, the KMT was able to rely on considerably more generous funding than was available to the DPP, as well as the support of much of the TV and print media in order to foreground the "1992 consensus." It also enjoyed massive support from the business world, which came out in favour of the "consensus," or more indirectly, of "stable relations between the two shores." (36) On the eve of polling day, for example, a group of 127 entrepreneurs placed an advertisement in Apple Daily stating, "In the present economic conditions, whoever supports the 1992 Consensus maintains stable relations between the two sides of the strait, which allows us in turn to govern without fear and to continue to take care of our employees and their families. (37)

Tsai Ing-wen could not find any way to get out of the path of such a steamroller. While she was in a strong position at the beginning of the campaign, when most of the debate was about the deterioration of the living and working conditions of the Taiwanese population, she got into difficulties once the spotlight shifted to how each side aimed to pursue the dialogue with Beijing and thus guarantee the preservation of the peace and its "dividends," as the KMT put it. The DPP could not recognise the "1992 Consensus" - which is to say a single China of which Taiwan would be a part - without betraying itself. But at the same time, it had to show that a different path was possible. Tsai Ing-wen strove to provide reassurance by stating that she would not renege on either the 15 technical agreements signed by the KMT government or even the ECFA, although the latter would be subject to careful re-examination. However she was not able to convince voters that her election and the return of the DPP would not mean a breaking-off of dialogue with Beijing and that it would not compromise the development of trade with China. Nor did she succeed in explaining how she would overcome Beijing's intransigence on the recognition of the principle of a single China as a precondition to any discussion, or in detailing the road map that was to accompany the

35. Tanguy Le Pesant, "An agreement that would belittle Taiwan?", China Analysis, no. 36, pp. 40-45.

36. Tanguy Le Pesant, "The business world mobilises for the re-election of Ma Ying-jeou," China Analysis, no. 37.

37. Apple Daily, 13 January 2012, p. 13. 
paradigm shift she was proposing, which is to say, "going towards China with the world, not going towards the world with China."

The series of polls taken about every two weeks by the TVBS station's survey centre shows that among voters between 20 and 29 who intended to vote, MaYing-jeou "bottomed out" in mid-November. A poll taken between 8 and 10 November showed that Tsai Ing-wen had 54 percent of the intended vote as against only 28 percent for Ma Ying-jeou and 8 percent for the third candidate, Soong Chu-yu.

Ma then began a gradual climb, overtaking Tsai Ing-wen at the beginning of January and maintaining a slight lead over his rival up to the election. A poll completed on 6 January gave Ma a two-point lead, with 41 percent, as against 39 percent for Tsai and 9 percent for Soong. Another, taken two days after polling day, showed that Ma Ying-jeou had maintained this lead and had also very probably benefited from the transfer of votes that had previously gone to Soong Chu-yu. Forty-five percent of the young respondents said they had voted for Ma Ying-jeou, 37 percent for Tsai Ing-wen, and 3 percent for Soong Chu-yu, with the remaining 5 percent not answering.

The interviews and discussions during the focus groups showed that it was her inability to get beyond the stage of criticism and to convince voters that she had a viable alternative that made Tsai Ing-wen finally lose a major part of the young floating vote. Her attacks on Ma Ying-jeou's record were indeed well founded and effective at the beginning of the campaign, but they were then replaced by a series of doubts: would the DPP candidate be able to put together a competent team; how much margin for manoeuvre did she have vis-à-vis Beijing; would she really be able to provide solutions to the economic and social problems she denounced? Her announcement on 6 January 2012, eight days before the poll, of the possibility of forming a coalition government if she was elected was far from reassuring.

\section{Conclusion}

In addition to the structural advantages that Ma Ying-jeou enjoyed (KMT funds, highly favourable media, solid constituency votes), Frank Muyard and Stéphane Corcuff agree that his re-election was the result of a choice by default. ${ }^{(38)}$ As they see it, there were many who finally voted for Ma despite the feeling of disappointment, or even strong antipathy, he aroused in them. These impressions are confirmed among the 20-to-29-year-olds. At the beginning of the campaign, support for Tsai Ing-wen was based on the disappointment caused by the unkept promises of Ma Ying-jeou, on the anxiety of the young about their future, on agreement with the criticisms made by the DPP candidate, and on hopes of a break and an alternative project for Taiwan. This support was not a given, however; despite what is often said, identification with the DPP is no stronger among the young than among the rest of the population. While it often has high ratings among that section of the population, these are usually temporary, thanks to some of its candidates and to the style of its campaigns. The KMT learnt a lot in this area from its defeats. It also managed to neutralise the question of identification with Taiwan. Consequently, many of the young voters who supported Tsai Ing-wen were likely to slip away from her at any time. This is what happened in the end, because Tsai did not manage to convince voters of the viability of her project vis-à-vis further development of economic relations with China. On the other hand, the support given to Ma by the Taiwanese business world, the United States, and of course China, certainly contributed to associating his re-election with the maintenance of a certain stability.

The changes in voting intentions of this generation therefore show both a certain pragmatism and an increasing tension between the attraction of Chinese economic power and the dynamic of the reinforcement of Taiwanese national identity. It also reflects its determination to maintain good relations with the unavoidable Chinese neighbour at a time when its historical protector, the US, seems to be in decline. However, while the young finally went over to Ma Ying-jeou and his "1992 consensus," it is above all because, for lack of anything better, they hope that Ma will be able to preserve the status quo, Taiwanese democracy, and peace in the Strait. It is therefore certainly not a vote in favour of closer political ties between the two sides of the strait, and even less of unification.

\section{Translated by Michael Black}

I Tanguy Le Pesant is an Assistant Professor at National Central University (Chongli, Taiwan), and is an associate researcher at the CEFC in Taipei.

38. Frank Muyard, "Les élections présidentielle et législatives de 2012. Analyses et perspectives" (The 2012 presidential and parliamentary elections: Assessment and perspectives), lecture at the Taipei subsidiary of the CEFC, 18 January 2012, www.cefc.com.hk/rubrique.php?id=74 (consulted on 7 May 2012); Stéphane Corcuff,"Taiwan au-delà des élections: identification plurielle, mais citoyenneté taiwanaise" (Taiwan beyond the elections: Plural identity, but Taiwanese citizenship), Sens Public, March 2012, www.sens-public.org/spip.php?article918\&lang=fr (consulted on 7 May 2012). 